\title{
East-West seesaw of SST variation in the mid-latitude North Pacific during the last two glacial cycles
}

\author{
Masanobu Yamamoto and Tadamichi Oba \\ Faculty of Environmental Earth Science, Hokkaido University; myama@ees.hokudai.ac.jp, oba-tad@ees.hokudai.ac.jp
}

The modern climates of the mid-latitude North Pacific margins are sensitive to the intensity of the summer North Pacific High and winter Aleutian Low, which are linked to the El Niño-Southern Oscillation (ENSO) and the Arctic Oscillation through atmospheric teleconnections. However, our understanding of past changes in the basin-scale climate of the North Pacific is still limited. Therefore, we compare the response of paleotemperature variation to orbital forcing at the Japan and California margins during the last two glacialinterglacial cycles (Yamamoto et al., 2004, 2007).

\section{Japan margin}

The Japan margin of the mid-latitude NW Pacific has a subarctic boundary between the subtropical Kuroshio and subarctic Oyashio currents. Core MD01-2421 was taken from a site located in the mixing zone of the Kuroshio Extension and Oyashio currents, and therefore, records past latitudinal displacements of the subarctic boundary (Fig. 1). The latitudinal position of the subarctic boundary, associated with the westerly jet in summer, is principally controlled by the relative intensities of the North Pacific High and the Okhotsk High.

At site MD01-2421, the alkenone $\mathrm{U}^{\mathrm{K}^{\prime}}{ }_{37}$-derived sea surface temperature (SST) varied from $13^{\circ}-23^{\circ} \mathrm{C}$ during the last $145 \mathrm{kyr}$ (Fig. 2). These SST increases lagged the benthic $\delta^{18} \mathrm{O}$-based MIS $1 / 2$ and $5 / 6$ boundaries by $\sim 1 \mathrm{kyr}$ and $\sim 4 \mathrm{kyr}$, respectively (Fig. 2; Yamamoto et al., 2004; Oba et al., 2006). Additionally, time series sediment-trap studies near the study site demonstrated that the flux-weighted $\mathrm{U}^{\mathrm{k}}{ }_{37}{ }^{-}$ derived temperature agreed with the summer SST. Examination of diatom, nannofossil and planktic foraminifer assemblages indicates that the alkenone SST was positively correlated with the Kuroshio contribution indices (Kuroshio current indicator species/[Kuroshio current indicator species + Oyashio current indicator species]). These findings suggest a periodic latitudinal displacement of the summer subarctic boundary in the northwestern Pacific.

\section{California margin}

The relative intensities of the California Current (CC) and the Southern California Countercurrent (SCC) are controlled by the development of the North Pacific High. The CC is intensified by a strengthened North Pacific High, whereas the SCC is intensified by a weaker North Pacific High.

We obtained $\mathrm{U}_{37}{ }_{37}$-derived SST differences for Ocean Drilling Program Sites 1014 and $1016\left(\Delta S S_{\text {NEPacific }}=\right.$ SST $_{\mathrm{ODP}_{1014}-}$ SST $_{\text {ODP1016 }} ;$ Fig. 1). Site 1014 is influenced by the northward invasion of the SCC into the California Borderland region, whereas Site 1016 is located along the main path of the CC. The $\triangle \mathrm{SST}_{\text {NEP }}$ must therefore, reflect the relative intensities of the $\mathrm{CC}$ and the SCC. The $\triangle \mathrm{SST}_{\text {NEP }}$ varied between $0.4^{\circ}$ and $6.1^{\circ} \mathrm{C}$, with an average of $2.9^{\circ} \mathrm{C}$ (Fig. 2). A high $\triangle S_{S T}$ (weaker CC) was observed in late MIS 2 and early MIS 5e, whereas a low $\triangle \mathrm{SST}_{\text {NEP }}$ (stronger $\mathrm{CC}$ ) was observed in mid-MIS 5e and MIS 1 (Yamamoto et al., 2007).

\section{East-west linkage}

Comparisons of the $\triangle S_{S S T}$ NEP and the SST of MD01-2421 at the Japan margin revealed an anti-phase variation (Fig. 2; Yamamoto et al., 2007). Both $\Delta S_{S S}$ NEP and the SST of MD01-2421 showed variation in 23-kyr and 30-kyr periods and lacked a 41-kyr period. The high $\triangle S_{S S T}$ NEP at the California margin (weakening of the CC) corresponded to low SST at the Japan margin (the southward displacement of the NW Pacific subarctic boundary), and vice versa (Fig. 2). The anti-phase relationship between $\triangle S_{\text {STT }}$ and the SST of MD01-2421 in the precession band suggests that variation in the Kuroshio-Oyashio boundary and in the CC system both responded to changes in the North Pacific High to precessional forcing.

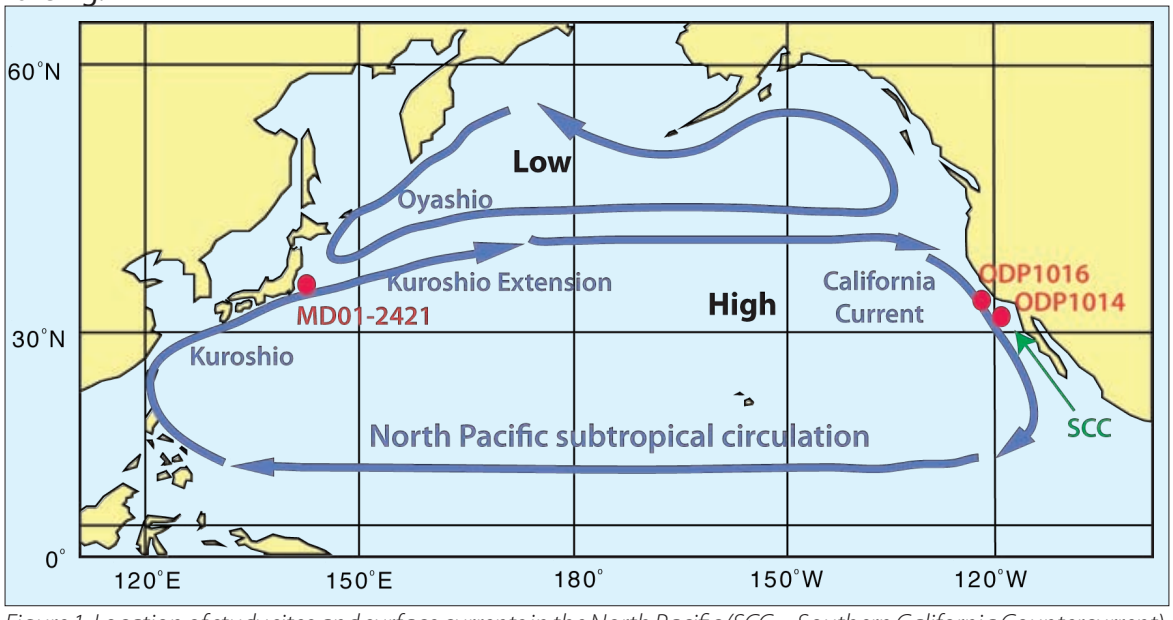

Figure 1: Location of study sites and surface currents in the North Pacific (SCC = Southern California Countercurrent). Local atmospheric cells are also indicated: High = North Pacific High, Low = Aleutian Low.

\section{Linkage with tropical Indo-Pacific climates}

Today, the North Pacific High is influenced by the modern interannual ENSO through atmospheric teleconnections. In El Niño years, the tropical convection center moves to the central and eastern equatorial Pacific. This process weakens the North Pacific High in summer. In La Niña years, the tropical convection center moves to the western equatorial Pacific, intensifying the summer North Pacific High.

Zebiak-Cane ENSO—a model used in the prediction of modern ENSO-calculations for the past $150 \mathrm{kyr}$ demonstrated that seasonal anomalies in insolation driven by precession could have changed ENSO behaviors (see the calculated NINO3 index-a SST anomaly in the eastern equatorial Pacific used to measure the strength of modern ENSO events-Fig. 2; Clement et al., 1999). At the precession band, the intensity minima of the North Pacific High were in phase with the April perihelion and the maxima of the predicted NINO3 index (Clement et al., 1999; Fig.2). This correspondence suggests that the intensity of the North Pacific High varied in response to precessional forcing and that this response is linked with the changes in tropical ocean-atmosphere interactions. However, the productivity variation in the tropical Indo-Pacific (Beaufort et al., 2001) was out of phase with the $\Delta \mathrm{SST}_{\text {NEP }}$ and the predicted NINO3. This phase discrepancy of long-term ENSO-like variability remains a key uncertainty because little is known about the behavior of tropical ocean-atmosphere interactions at orbital 


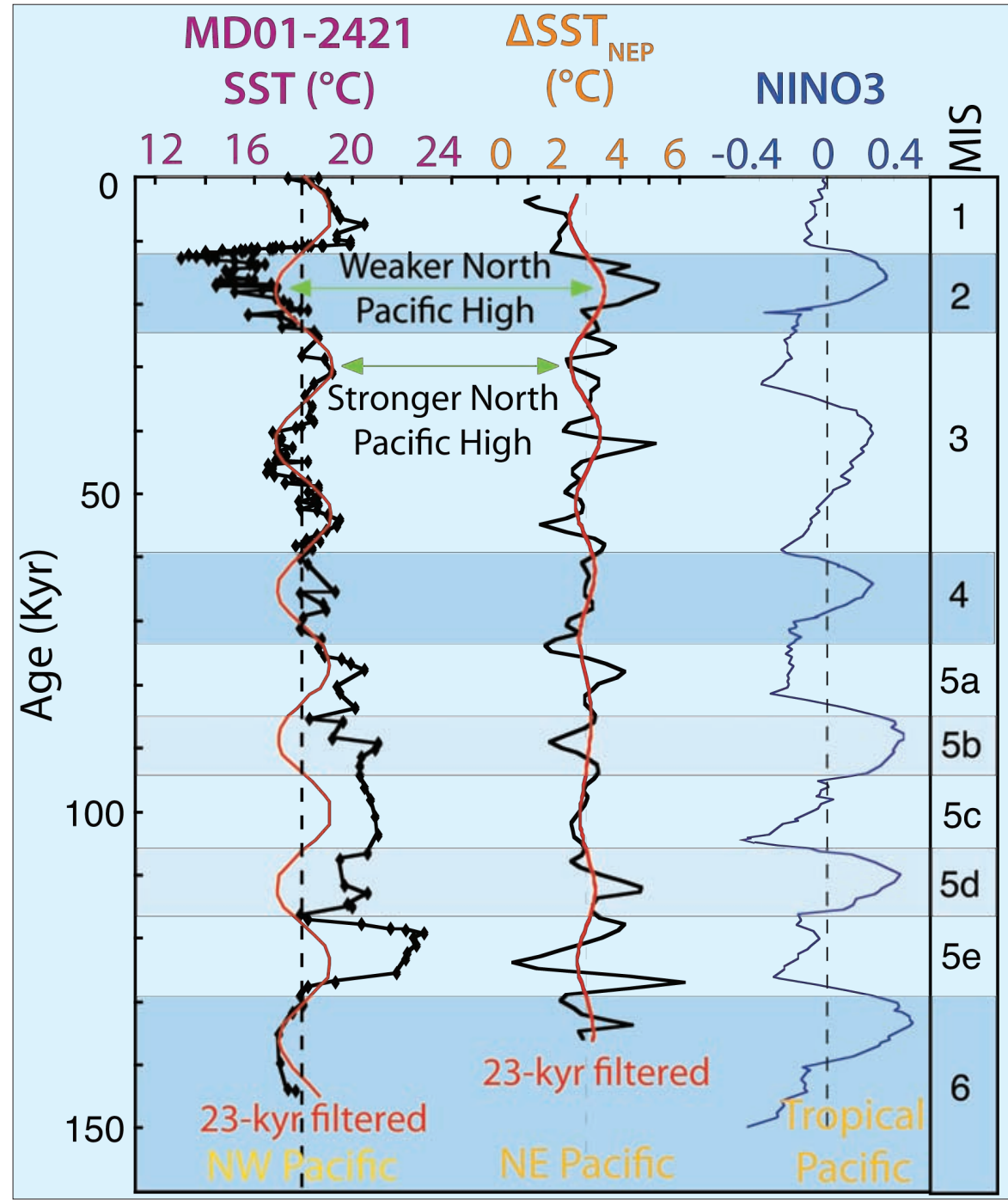

Figure 2: Uk' -derived SST at the Japan margin (core MD01-2421; Yamamoto et al., 2004, 2005), lateral temperature gradient $\triangle S S T$ at the California margin, and the calculated NINO3 index (Clement et al., 1999) during the last $150 \mathrm{kyr}$. MIS = Marine 1 sotope Stage

timescales, although some shorter paleorecords in the eastern tropical Pacific and the tropical Andes regions are consistent with the model prediction (e.g., Koutavas et al., 2002; Moy et al., 2002). Long-term ENSO-like variability and wave propaga- tion by teleconnection (Clement et al., 1999; Beaufort et al., 2001; Yamamoto et al., 2004) are potential driving forces of the North Pacific basin-scale climate response. The establishment of the linkage between this basin-scale response and tropical ocean-atmospheric dynamics will be a critical step toward better understanding the role of the Indo-Pacific in global climate change.

In summary, the east-west seesawlike SST variation in the mid-latitude North Pacific during the last two glacial-interglacial cycles is part of a basin-scale oceanic and atmospheric response to precessional forcing. As this east-west seesaw is also typical of the modern North Pacific on interannual and decadal timescales, common climate-driving processes might exist in the response of the North Pacific to forcing on different timescales.

\section{Note}

Data are available from NOAA Paleoclimatology website www.ncdc.noaa.gov/paleo/paleo.html

\section{References}

Beaufort, L., de Garidel-Thoron, T., Mix, A.C. and Pisias, N.G., 2001: ENSO-like forcing on oceanic primary production during the late Pleistocene, Science, 293: 2440-2444.

Clement, A.C., Seager, R. and Cane, M.A., 1999: Orbital controls on the El Niño/Southern Oscillation and the tropical climate, Paleoceanography, 14: 441-456.

Yamamoto, M., Oba, T Shimamune, J and Ueshima, T, 2004: Orbitalscale anti-phase variation of sea surface temperature in midlatitude North Pacific margins during the last 145,000 years, Geophysical Research Letters, 31: L16311.

Yamamoto, M., Suemune, R. and Oba, T., 2005: Equatorward shift of the subarctic boundary in the northwestern Pacific during the last deglaciation, Geophysical Research Letters, 32: L05609.

Yamamoto, M., Yamamuro, M. and Tanaka, Y., 2007: The California current system during the last 136,000 years: response of the North Pacific High to precessional forcing, Quaternary Science Reviews, 26: $405-414$.

For full references please consult:

www.pages-igbp.org/products/newsletter/ref2008_1.html

\section{Last glacial SST changes in the SE Pacific-a bipolar see-}

\section{saw perspective}

JÉrôme KaISER ${ }^{1}$ and Frank Lamy ${ }^{2}$

${ }^{1}$ Royal Netherlands Institute for Sea Research, Texel; jkaiser@nioz.nl; kaiserj@gfz-potsdam.de

${ }^{2}$ Alfred Wegener Institute for Polar and Marine Research, Bremerhaven, Germany; frank.lamy@awi.de

The SE Pacific is a key region for studying natural variability of globally important atmospheric and oceanic circulation components of the southern hemisphere, from the last glacial and beyond. High resolution paleoceanographic studies have particularly focused on continental margin records off Chile, which were recovered by several international research cruises during the last decade, including Ocean Drilling Program (ODP) Leg 202. The current network of sediment cores along the northern and central Chilean margin have greatly improved our understanding of late Quaternary terrestrial climate change in Chile (e.g., Hebbeln et al., 2007; Lamy et al., 1998, 1999, 2001; Stuut and Lamy, 2004) and the paleoceanography of the adjacent Peru-Chile Current (PCC) system (e.g., Hebbeln et al., 2002; Kim et al., 2002; Mohtadi and Hebbeln, 2004). These findings are summarized in two recent review articles (Marchant et al., 2007; Stuut et al., 2006).

Here, we focus on results based on ODP Site 1233, located at the upper con- tinental slope off southern Chile $\left(41^{\circ} \mathrm{S}\right)$ at the northern margin of the Antarctic Circumpolar Current (ACC) and the southern end of the PCC (Fig. 1). This site has received particular attention because the $\sim 70$-kyr-old sequence extends over $\sim 135$ $\mathrm{m}$ composite core depth, resulting in high sedimentation rates, unprecedented in the South Pacific. Site 1233 is ideally located to compare past variations of both surface and deep-ocean water masses with climate records from high southern latitudes (e.g., Antarctic ice-cores). Modern sea sur- 